\title{
DEMAND FOR LOCALLY PROVIDED PUBLIC SERVICES WITHIN THE MEDIAN VOTER'S FRAMEWORK: THE CASE OF THE BRAZILIAN MUNICIPALITIES
}

\author{
Constantino Cronemberger Mendes \\ Departamento de Economia, Universidade de Brasília and IPEA, Brasília \\ SBS-Q-1, B1. J, Ed. BNDES/IPEA, sala 318, Brasília-DF, 70910-900, Brazil \\ Tel/fax: (061) 315-5174; e-mail: ccmendes@unb.br \\ Maria da Conceição Sampaio de Sousa \\ Departamento de Economia, Universidade de Brasília \\ Campus Universitário Darcy Ribeiro S/N, Brasília-DF, 70910-900, Brazil \\ Tel/fax: (061) 347-5304; e-mail: mcss@unb.br
}

Brasília, May 2004

\begin{abstract}
Neste estudo estimamos a demanda para a despesa pública local nas municipalidades brasileiras dentro de uma abordagem do eleitor mediano. Os resultados obtidos são consistentes com a teoria que sugere esta hipótese como útil para descrever a demanda para bens públicos locais no Brasil. $\mathrm{O}$ uso da regressão quantílica permite investigar os impactos das variáveis nas despesas públicas locais através de diferentes classes de despesas, avaliando a heterogeneidade municipal. Nossos resultados sugerem também que o impacto do tamanho da cidade na qualidade de bens mostra efeitos de aglomeração entre zero e um. Entretanto, o congestionamento marginal diminui ligeiramente com a despesa, resultado este surpreendente porque sugere que o efeito congestionamento deve ser mais elevado em cidades grandes. As indivisibilidades que impossibilitam a provisão de determinados serviços em cidades pequenas concentram sua provisão em cidades maiores. As despesas mais elevadas daquelas cidades grandes refletem não somente um custo de aglomeração, mas também o fato que estas cidades oferecem uma escala maior de serviços. Assim, no Brasil, contrário aos resultados tradicionais, o efeito reduzido do congestionamento ao longo das classes da despesa reflete a predominância dos elementos da escala medidos pelas elasticidades da população sobre os efeitos do preço.
\end{abstract}

Palavras-chave: Serviços Públicos Locais, Teoria do Eleitor Mediano; Método Regressão Quantílica.

\begin{abstract}
In this paper we estimated the demand for local public spending for the Brazilian municipalities within a median voter's framework. Results obtained are consistent with the theoretical background thus suggesting that this hypothesis might be useful to describe the demand for local public goods in Brazil. In particular, the use of quantile regression permitted to investigate the impacts of the conditioning variables on local public expenses across different expenditures classes thus allowing for heterogeneity across municipalities. Our results also suggest that the impact of the city size on the quality of club goods shows crowding effects as $\gamma$ is between zero and one. However, in the estimated models, marginal congestion slightly decreases with expenditure. This is a rather surprising result as one is tempted to conclude that the congestion effect should be higher on big cities. Yet, a more careful look shows the drawbacks of such interpretation. The indivisibilities that preclude the provision of certain services in small towns, concentrate their provision on larger cities. Hence, the higher expenditures of those big cities reflect not only a crowding cost but also the fact that these towns offer a wide range of services when compared to the small ones. So, in Brazil, contrary to the traditional results, the reduced congestion effect along the spending classes reflect the predominance of the scale elements measured by the population elasticities over the price effects.
\end{abstract}

Key Words: Local Public Services; Median Voter Hypothesis; Quantile Regression Method. JEL Classification: H70, H72, C31. 


\section{INTRODUCTION}

The evaluation of the public expenditure has become an area of increasing interest since the seminal work of Samuelson (1954). Theoretical advances of the theory of public goods took into account the particularities of the provision of those services at a local level (Tiebout, 1956). Tiebout's key insight was that this problem is different when local governments provide goods to citizens who can move among distinct jurisdictions. If citizens are faced with an array of communities that offer different types or levels of public goods and services, then each citizen will choose the community that best satisfies his or her own particular demands. Individuals effectively reveal their preferences by "voting with their feet." Competition among jurisdictions results in homogeneous communities, with residents that all value public services similarly. In equilibrium, no individual can be made better off by moving, and the market is efficient, thus not requiring a political solution to provide the optimal level of public goods.

A vast literature in local public finance has built on the Tiebout's hypothesis about community choice to estimate demands for local public goods and to verify to what extent property values reflect area taxes and services. Among those works we find the seminal studies of Borchesing and Deacon (1972) and Bergstrom and Goodman (1973). Their motivation was to test the validity of the median voter theorem that provides a method of aggregating individual voter's demands to obtain community demand. Under a set of strong hypotheses such as a single-peaked preferences and a single-dimensional public good and by using the voter with median income as a proxy for the median voter, these studies estimated demand functions for various local public services. The rationale for applying the median voter theorem to the study of local public services came from the fact that in federal systems voter's preferences are more likely to be reflected at the local level as the consumers of public services have a better knowledge of the benefits and costs of the local public expenditures. Median income and an index of median tax prices as well as variables supposed to capture demographic and institutional characteristics have been used as explanatory variables. Later on, Bergstrom, Rubinfeld and Shapiro (1982) applied a new method for estimating demand for local public goods from survey data. Individuals' responses to questions about whether they wanted more, less, or the same amount of various local public goods are combined with observations of their incomes, tax rates, and the amounts of actual spending in their home communities. Parameter estimates turn out to be quite similar to those found with studies like Bergstrom and Goodman's study based on total expenditures across communities. The authors consider that the fact of similar estimates to be derived from two different types of data indicates the robustness of both approaches

The robustness of the median voter framework is corroborated by several recent studies. Empirical research, such as those presented by Aronson, Lundberg and Wikström (2000), Doi (1998), Dahlberg and Jacob (1998, 2000), Turnbull and Djoundourian (1994), Turnbull and Chang (1998), Gross (1995), tends to support the hypothesis that the median voters' preferences determine government fiscal behaviour. In particular, it was suggested that the median voter model provides a better explanation of large-scale public programs than comparable interest group models (Congleton and Shughart (1990), Congleton and Bennett (1995)). A good survey of this literature could be found in Reiter and Weichenrieder (1997), which presented a conceptual and methodological critical survey covering the empirical literature on the demand for local public goods. 
As usual, the main problems plaguing those studies are related to the aggregation criteria of the preferences. The usual solution, based on the theorem of the median voter, do not guarantee, under the current political process, that provision of a local public good will, indeed, represent the amount demanded by any individual in the community. Other sources of problems include measurement errors in variables, the heteroskedasticity and/or autocorrelation that can result in biased estimators. Also, the estimated values for the elasticities are questioned as, de facto, these studies do not measure the demand for public goods, but only public expenditures. Last, but not least, empirical results for local public services, based on the value of the estimated congestion parameters, compel some economists to conclude prematurely that those services could be privatized. They argue that if the crowding is not induced by rivalry in the consumption of public services, but rather by negative agglomeration externalities, crowding elasticities close to unity do not imply that these services can be efficiently be supplied by "private competing clubs". If the production of public services presents economies of scale, competition between jurisdictions may lead to a sub-optimal provision of those services. To tackle those problems, recently, a new line of research using nonparametric tests, inspired by Varian's critique $(1982,1990)$ based on the theory of reveled preferences, tried to validate the median voter hypothesis ((Turnbull and Chang (1998), Baudry, LePrince and Moreau (2002)). Their results contribute to reinforce the median voter hypothesis as a useful approximation of governance within a democratic context. Further, it was found that the single service and single tax base assumptions are not critical to the empirical performance of the median voter model. Yet, Turnbull and Djoundourian (1994), by using the Cox specification test, using data from general purpose municipal governments, found that the median voter hypothesis is appropriate for explaining the aggregate behaviour of municipal governments but does not perform so well when applied to specific services.

As for Brazil, recently, Sampaio de Sousa and Stosic (2003a) and Sampaio de Sousa, CribariNeto and Stosic (2003b) applied nonparametric techniques (DEA - Data Envelopment Analysis and FDH - Free Disposal Hull) to measure the level of technical efficiency of the Brazilian municipalities by using a multiple input output framework. These studies represent an attempt to compute robust efficiency scores for evaluating Brazilian municipalities using the 2000 census data. This approach highlights the efficiency aspects of local public spending. Under this approach, the emphasis is placed on the determination of a cost-efficiency frontier associated with the production of public goods that would permit to estimate the efficiency levels of the various municipalities. The above-mentioned approach focuses on the supply aspects of the provision of local public goods. To our best knowledge no study has attempted to investigate the determinants of the demand for local public goods in Brazil following the tradition initiated by the seminal papers by Borchesing and Deacon (1972) and Bergstrom and Goodman (1973). This type of analysis is particularly appropriate to explain the levels and distribution of the various local services. Besides, the knowledge of demand functions for public services serves various purposes: they allow us to know the outcomes of alternative political decision methods and tax structures in a particular locality. They disclose the existence economies of scale at the municipal levels and help to assess the effects of changes in the demographic and economic variables on the amount of services to be demanded. For those reasons, analysing the demand side may add relevant information on the provision of such goods thus being a useful complement the previous referred studies.

The objective of this paper is to assess the demand for local public services in the Brazilian municipalities within a median voter framework. In order to achieve our purpose we will employ quantile regression techniques, introduced for Koenker and Basset (1978). We hope this study 
will contribute to the recent debate, in Brazil on the economics of decentralization by helping to establish quantitative parameters for those discussions.

This paper unfolds as follows. Section 2 describes the theoretical model based in the median voter framework. Section 3 describes the data and variables. Section 4 presents the econometric model. Section 5 presents the econometric results. Finally, Section 6 summarizes the main conclusions.

\section{THE MEDIAN VOTER MODEL}

In this model, individuals maximize a quasi-concave utility function subject a budget constraint. The price of the private good $(x)$ has been normalized to be equal to 1 . All individuals within the jurisdiction consume the same level of the public service, herein denoted by $\mathrm{z}$, whose price is $\mathrm{p}_{\mathrm{z}}$. The others variables are the individual median income $\left(y_{m}\right)$, the tax share $\left(t_{i}\right)$ and level of locally raised taxes or total tax revenue $(\mathrm{T})$. The quantity supplied of a public commodity by a given locality is equal to its median quantity demanded by its citizens which median income. Hence, the individual's problem consists in maximizing its utility function, given by:

[1] $u\left(x_{i}, z\right)$

Subject to the its budget constraint:

[2] $y_{m}=x+t_{i} b_{m}$

where $y_{m}$ represents the income of the median voter, $b_{m}$ its tax base and $t$ the tax rate. The individual's demand functions depend also on the government's budget constraint, given by:

$[3] c Z=G+t B$

where $c$ is the constant marginal and average cost of production of public service ${ }^{1}$, $t B$ corresponds to total tax revenues and $\mathrm{G}$ represents the intergovernmental grants received by the municipality. Rearranging (2) we have:

[4] $t=[c Z-G] / B$

Due to the presence of congestion (or crowding out) in consumption, the quality of the public service depends on the size of the community's population $(\mathrm{N})$. Using the proportional metric proposed by Bocherding and Deacon (1972), the congestion function may be written as:

$[5] Z=N^{\gamma} z$

where $\gamma$ measures the crowding out or congestion effect. If $\gamma$ is one, the public good is private and there is no benefit from scale economies for the community: the individual consumption is equal to $1 / \mathrm{N}$. On the other hand, if $\gamma$ is zero the good is a purely public good. Notice that if $\gamma$ is higher than one the good is marginally overcongested (Reiter and Weichenrieder (1999)). Every

\footnotetext{
${ }^{1}$ Bergstrom and Goodman (op.cit., p. 280) showed that this will be possible even if communities produce public goods using some local inputs whose prices may differ from place to place, so long as all municipalities have identical, homothetic production functions and face horizontal supply curves for inputs.
} 
additional user requires an increase in the supply of $\mathrm{Z}$ so as to keep $\mathrm{z}$ constant. Values of $\gamma$ between 0 and 1 allow for the possibility of goods that have partly private and partly public characteristics, where crowding effects are presents but there are still economies of scale in consumption.

Using (3) and (5) in the median voter's budget constraint gives:

[6] $y_{a}=y_{m}+g\left(b_{m} / b\right)=x+\left(b_{m} / b\right) c N^{\gamma-1} z$

where $\mathrm{y}_{\mathrm{a}}$ corresponds to the median revenue increased by its share of per capita intergovernmental grants, $g=G / N$, and $b=B / N$, where $B$ stands for the total tax base. The median voter's income plus its share of the per capita intergovernmental transfer must finance its privates expenses as well as its cost share on the public good $\left(b_{m} / b\right) N_{i}{ }^{\gamma-1} z$. Rewriting [6] we have:

[7] $x=y_{m}+\left(b_{m} / b\right)\left[g-c N^{\gamma-1} z\right]$

Replacing [7] in [1] yields the following maximization problem:

[8] $\max u=u\left[\left(y_{m}+\left(b_{m} / b\right)\left[g-c N^{\gamma-1} z\right]\right), z\right]$

Assuming that the maximization of [8] yields the median voter's demand function for the local public good, $\mathrm{z}$, we have:

[9] $z=z\left[y_{a},\left(b_{m} / b\right), N\right]$

Defining the tax price of the public service as the individual cost of purchase one additional monetary unit of the local public services it can be derived by differentiating $\mathrm{y}_{\mathrm{a}}$ with respect to $\mathrm{z}$. The tax price is therefore:

[10] $\partial y / \partial z=p=\left(b_{m} / b\right) c N^{\gamma-1}$

Each consumer knows his own tax price and is able to determinate the amount of commodity ${ }^{2}$ which his choose for the community. Supposing that the demand function defined by [9] z $=f(p i$, $y_{a}$ ) is characterized by constant price and income elasticity, this demand can be written as:

[11] $z=\alpha p^{\beta 1} y^{\beta 2}$

Using [10], rearranging the terms and re-written in log form yields the model for the demand to be used here:

$[12] z=\alpha\left[\left(b_{m} / b\right) c N^{\gamma-1}\right]^{\beta 1} y_{a}^{\beta 2}$

Writing [10] in terms of Z, by means of [5] we have:

[13] $Z=z N^{\gamma}=\alpha\left[\left(b_{m} / b\right) c N^{\gamma-1}\right]^{\beta 1} y_{a}^{\beta 2} N^{\gamma}$

\footnotetext{
${ }^{2}$ Reiter and Weichenrieder (1997, p. 21) showed three reasons why electors may misperceive the costs of public services: "fiscal illusion"; "flypaper effect" and "revenue-complexity"
} 
Finally, adding a vector $\Omega$ of socio-economic characteristics, which are expected to influence demand, and multiplying [13] by $p$ leads to an estimable function of local, E:

[14]E $=p Z=p z N^{\gamma}=\alpha\left[\left(b_{m} / b\right) c N^{\gamma-1}\right]^{1+\beta 1} y_{a}{ }^{\beta 2} N^{\gamma} \Omega^{\beta 3}$

Equation [15] represents the standard estimation equation for analyzing the demand for locally supplied public goods:

$[15] \operatorname{Ln} E=k+\left(1+\beta_{1}\right)\left[\ln \left(b_{m} / b\right)\right]+\beta_{2}\left(\ln y_{a}\right)+\beta_{3}(\ln \Omega)+.\beta_{4}\left(\ln N_{i}\right)+\varepsilon i$

With $k=\ln \alpha+\left(1+\beta_{1}\right) \ln c$

where $\left(1+\beta_{1}\right)$ is the price elasticity of the demand. The population elasticity, $\beta_{4}$, satisfy the following equation:

$[16] \beta_{4}+\beta_{1}=\chi\left(1+\beta_{1}\right)$

\section{DATA AND VARIABLES}

The data used in this study were obtained from the Census 2000 of IBGE (Instituto Brasileiro de Geografia e Estatística - Brazilian Institute of Geography and Statistics). The sample consists of 3.427 municipalities out of a total of 5.264 Brazilian municipalities. The communes for whom some information was missing were excluded of the data set. Data on local tax revenues was obtained from STN (Secretaria do Tesouro Nacional - National Treasure Secretariat). Table 1 provides the complete list of variables.

The dependent variable of the model, E represents the value of municipal current spending. The explanatory variables are described as follows: firstly, in Models 1 and 2, the tax share variable $(\mathrm{bm} / \mathrm{b})$ accruing to the citizen with the median income is computed as the local tax revenue divided by the total tax revenue (total revenue across municipalities). In Models 3 and 4 we define the tax price as the ratio between the median and average income. The median income is denoted $y_{m}$ and $\mathrm{N}$ is the number of citizens in a municipality or total population. 
Table 1: Dependent and Explanatory Variables: A Brief Description

\begin{tabular}{|c|c|}
\hline Dependent Variable & Description \\
\hline Local Public Spending - E & The value of municipal current spending. \\
\hline Explanatory Variables & Description \\
\hline Distance & "Spatial" variable, to show the relevance of neighborhood effect. \\
\hline Tax share $-b_{m} / b$ & $\begin{array}{l}\text { The tax share of the citizen with the median income, calculated by two } \\
\text { criteria: first, total revenue local/total revenue general; and second, } \\
\text { based on the ratio between the median and the average income. }\end{array}$ \\
\hline Median Income - $y_{m}$ & $\begin{array}{l}\text { Median earnings, calculated by two criteria: median income plus tax } \\
\text { share (two criteria) x per capita intergovernmental grants. }\end{array}$ \\
\hline Total Population - N & Number of citizens in a municipality (total population). \\
\hline$\%$ Population $>60$ years old & Citizens older than 60 in percent of total population. \\
\hline $\begin{array}{l}\text { Matrix } \Omega \text { (socioeconomic } \\
\text { characteristics) }\end{array}$ & Description \\
\hline Demographic Density & Population/area of the community (scale variable). \\
\hline Hospital and Health Services & Health variable, as a proxy for health services. \\
\hline Enrollment & $\begin{array}{l}\text { Education scale variable. Data refers to primary and secondary } \\
\text { enrollment in municipal schools. }\end{array}$ \\
\hline $\begin{array}{l}\% \text { of Households whose Head Earns } \\
\text { up to } 1 \text { Minimum Wage }\end{array}$ & Poverty proxy. \\
\hline Dummy variables & Description \\
\hline Capital & If the community is ( 1$)$ or is not (0) state capital. \\
\hline $\begin{array}{l}\text { Participation in Inter-Municipal } \\
\text { Consortia }\end{array}$ & $\begin{array}{l}\text { Proxy to administrative coordination and organization among } \\
\text { municipalities. }\end{array}$ \\
\hline Draught Area (Poligono da Seca) & $\begin{array}{l}\text { Municipalities located in this area, hit by adverse climatic condition } \\
\text { take } 1 \text {; zero otherwise. }\end{array}$ \\
\hline $\begin{array}{l}\text { North, Northeast, Southeast and South } \\
\text { Regions }\end{array}$ & $\begin{array}{l}\text { Proxies to evaluate for regional and geographic influence. } \\
\text { Municipalities located in these regions take 1; zero otherwise }\end{array}$ \\
\hline Political Parties (PT and PDT) & Political party of the mayor. \\
\hline
\end{tabular}

\section{THE ECONOMETRIC MODEL}

Let $n$ be the number of municipalities, $y=\left(y_{1}, \ldots, y_{n}\right)^{\prime}$ the vector of municipal expenses, $X$ a matrix of dimension $n \times p$, containing the municipality characteristics, $\beta$ a $p$-dimensional vector of unknown parameters and and $u$ an $n$-dimensional vector of random errors. We can write a regression model as

$$
y_{t}=f\left(x_{t} ; \beta\right)+u_{t}, t=1, \ldots, n \text {. }
$$

Here, $x_{t}$ denotes the $p$-dimensional vector of the characteristics of the $t$-th municipality. As we do not have a priori information about the functional form of $f$, its is common practice to assume linearity:

$$
y=X \beta+u
$$

Another important aspect of modeling in classical regression, in our particular case, is the possibility of existence of spatial effects due to the existence of some functional relationship between the municipal efficiency structures in two distinct points in space. The smaller the area 
where those points are located, the higher the probability of geographical correlation. Anselin (1988) proposed the following model to explicitly consider the spatial dependency:

$\theta=\rho W y+X \beta+u$, with $u=\lambda W u+e$,

where $W$ is a $n \times n$ matrix that controls for the existence of a neighborhood effects. Here, the parameter $\rho$ measures the spatial correlation that, if different from zero, implies that the computed efficiency score of a given municipality is directly affected by the scores of its neighbors. The parameter $\lambda$ captures the spatial correlation between the errors and $e$ is a new error term. $^{3}$

Here we will use two forms for the $W$ matrix: first, the element $(i, j)$ from $W$ will be one if municipalities $i$ and $j$ are neighbors and zero otherwise, neighborhood being defined as geographical distance that does not exceed 50 kilometers; secondly, the element $(i, j)$ from $W$ will be equal to the distance between municipalities $i$ and $j$ divided by the maximum distance encountered; hence, we have a measure between zero and one for all pairs of localities and not only a binary measure of neighborhood.

As the municipalities differ significantly on various aspects, it is reasonable to expect that their associated regression errors also display different variances. Thus, when estimating the parameters we should take into account the existence of heteroskedasticity.

\section{ECONOMETRIC RESULTS}

Results obtained by using the classical OLS model are presented in Table 2 and should serve as a counterpoint for the ones obtained by using quintile regression estimators. Notice that the estimates shown in Table 2 are corrected by the statistics of White, for heteroskedasticity as we are dealing with cross section data.

Firstly, we observe that all the parameters are significant and show the expected sign. Notice that results shown in Table 2 suggest the relevance of the neighborhood effect in the spatial distribution of the spending patterns. Indeed, in all four models considered, we found a positive spatial correlation, thus indicating that higher spending levels tend to spread out, at least, partially, to the surrounding localities, in some sort of spill over or "demonstration effect".

The low values for the estimated coefficients for the price variable are on the ranges of the ones found on the empirical literature (see Reiter and Weicherieder (1997)) and point out to a very inelastic demand as far as this variable is concerned. This is particularly true when the tax price of the i-th municipality is based on fiscal effort, defined as its participation on the total municipal tax revenue, used in Model 1 to 2. Notice that on models 3 and 4, we defined the tax share as the ratio between the median and the average income. In spite of the main difficulties in estimating the tax price, including the ones caused by measurements errors, this result is quite robust and seems to hold even under extreme assumptions (Bergstrom and Goodman (1973)).

As for the income variable, we found that the income elasticity of municipal expenditures is positive and inferior to the unity as attested by previous studies (see for example, Reiter e

\footnotetext{
${ }^{3}$ Notice that there is no direct interest in the estimation of $\lambda$ and $\rho$.
} 
Weicherieder (1997)). The estimated coefficients range from 0,47 to 0,58 showing that municipal public spending in Brazil is not a luxury although our estimates are clearly above the international average, according to which those goods conform more to the pattern of "basic" needs. Finally, as expected, a higher population increases the demand for public goods.

Regarding the crowding out effect, let us compute the value for the parameter $\gamma$, which accounts for this effect. Its computed value, ranges from 0,66337 to 0,64524, respectively, for Model 2 and 4. This is clearly below the values found by the recent studies (Baudry, Leprince and Moreau (2002), Guengant, Josselin and Rocaboy (1995, 2002)) including the one reviewed by Reiter and Weicherieder (1997), where this parameter tends to be higher than one, thus implying a strong congestion effect. Those studies, following the Borchesing and Deacon (1972) and Bergstrom and Goodman (1973) results, give little evidence that local governments provide services characterized by economies of scale in consumption. Yet, the diverging result obtained for the Brazilian communes is hardly surprising. This comparatively large public ness of governmentsupplied goods may be explained by the small size of the typical Brazilian municipalities. We should expect a lower congestion effect in presence of significant economies of scale in the consumption that makes most of the municipality's facilities oversized, as is the case, for example, with the undersized Brazilian communal hospital and schools. Indeed, an increase in the number of inhabitants would lower the tax price of the publicly provided good as its cost is shared by a larger group (Sampaio de Sousa, Cribari-Neto and Stosic (2003)). Of course the value of this parameter strongly depends on the definition of the tax rate. Yet, even when we use a different definition, our estimates were kept significantly below the unity.

Let us now turn to the analysis of impact of the socioeconomic characteristics of the communes on their spending pattern. It is interesting to see that, for a municipality, the fact of being a capital exerts a powerful influence upon public spending. This important result confirms the role played by those cities, which are at the center of political power, in centralizing the demand pressures for public services in their respective states and/or influence area. Observe also that being a municipality situated on the Polígono das Secas leads to a lower demand for public goods. However, those results should be carefully examined as this program (Polígono das Secas) includes some of the poorest communes of the Northeast region. As for the regional impact, our results show that municipalities belonging to the Northeast and Southeast Regions tend to present higher expenses levels. This is consistent with the ideas that, for different reasons, both regions have, indeed, a greater demand for public services. In the poor Northeast region, public services are, frequently, the only ones available to an impoverished population as its private substitutes are lacking. In the relatively rich Southeast region, this increased demand for public goods may be due to its more urban characteristics. As for the Northern Region, the lowest demand may be due to poor data and its huge dimension and scattered municipalities; this may lead to distortions on the regional results.

The scale variables included in the analysis were relevant for explaining expenditures in all models we estimated. As expected, this variable exerts a negative effect on public expenses, thus corroborating previous insights suggested by the nonparametric analysis described in previous studies (Sampaio de Sousa, Cribari-Neto and Stosic (2003)). In particular, the relatively higher expenses of cities with very low demographic density rates is most likely due to the presence of local increasing returns to scale prevalent among small municipalities. The scattered population on those cities raises the average costs of public services, thus preventing them from exploiting the economies of scale that characterizes the production of those services, and so they fail to 
optimally use their resources. ${ }^{4}$ On the other hand, higher density rates decrease the costs of the above-mentioned services, and hence contribute to reduce expenses. By the same token, the inverse relationship between public expenses and participation in inter-municipal consortia may be due to the fact that, ceteris paribus, the coordination among neighbor municipalities to provide services, characterized by high fixed costs, as hospital, contributes to optimize the scale of operations and cut costs. This is highly desirable as those consortia permits to reduce expenses while expanding the services. Finally, concerning the variables Hospital and Health Services and Enrollment, they have, as expected, a significant and positive effect on municipal expenditures.

Table 2: Determinants of the Demand for Local Public Goods in Brazilian Municipalities - 2000 - OLS Results

\begin{tabular}{|c|c|c|c|c|}
\hline \multirow[t]{2}{*}{ Explaining Variables } & \multicolumn{4}{|c|}{ Dependent Variables: Aggregate Municipalities' Expenditures } \\
\hline & Model 1 & Model 2 & Model 3 & Model 4 \\
\hline Intercept & $5,6196(21,6122)$ & $5,6213(21,6427)$ & $4,1342(16,5561)$ & $4,1569(16,62589)$ \\
\hline Distance & $0,03875(5,8909)$ & $0,3970(6,11212)$ & $0,04397(6,6601)$ & $0,04522(6,926657)$ \\
\hline Tax Share & $-0,0340(-6,3011)$ & $-0,0338(-6,23428)$ & $-0,194037(-6,1332)$ & $-0,19042(-6,038849)$ \\
\hline Median Income & $0,4747(15,982)$ & $0,4777(16,2698)$ & $0,5823(17,7225)$ & $0,58365(17,93487)$ \\
\hline Capital & $0,68054(8,6128)$ & $0,67692(8,61607)$ & $0,6608(8,50941)$ & $0,6536(8,501393)$ \\
\hline Demographic Density & $-0,0643(-8,8997)$ & $-0,06174(-8,9408)$ & $-0,065236(-9,07344)$ & $-0,0628(-9,13747)$ \\
\hline Hospital and Health Services & $0,0589(6,4920)$ & $0,0604(6,657657)$ & $0,052833(5,642010)$ & $0,05354(5,719242)$ \\
\hline Enrollment & $0,0922(13,1881)$ & $0,09057(13,2682)$ & $0,09681(13,82592)$ & $0,095378(13,91141)$ \\
\hline $\begin{array}{l}\text { Participation in Inter-Municipal } \\
\text { Consortia }\end{array}$ & $-0,0414(-3,4410)$ & $-0,0389(-3,32491)$ & $-0,04411(-3,6555)$ & $-0,040621(-3,44649)$ \\
\hline Total Population & $0,6773(53,9785)$ & $0,67475(54,1039)$ & $0,71408(68,27859)$ & $0,712795(69,48778)$ \\
\hline$\%$ Population $<15$ years old & $-0,0069(-0,4395)$ & - & $0,008834(0,5660)$ & 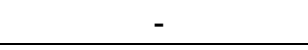 \\
\hline$\%$ Population > 60 years old & $-0,0488(-2,8913)$ & $-0,05476(-5,4161)$ & $-0,0180(-1,1595)$ & $-0,009369(-1,34628)$ \\
\hline$\%$ Households Earning 1M.W. & $0,0056(0,50147)$ & $0,00627(0,57199)$ & $0,0197(1,6581)$ & $0,020627(1,756072)$ \\
\hline Polígono das Secas & $-0,0388(-2,3610)$ & $-0,03823(-2,3461)$ & $-0,030076(-1,8131)$ & $-0,031452(-1,90908)$ \\
\hline Northeast Region & $0,1011(3,4023)$ & $0,07807(3,18388)$ & $0,133582(4,336)$ & $0,104999(4,101938)$ \\
\hline Northern Region & $-0,1238(-4,1218)$ & $-0,1430(-5,29185)$ & $-0,127417(-4,2012)$ & $-0,145595(-5,32613)$ \\
\hline Southeast Region & $0,1458(6,2549)$ & $0,119971(8,8518)$ & $0,16247(6,9253)$ & $0,129772(8,680201)$ \\
\hline South Region & $0,0296(1,2620)$ & - & $0,0392(1,6746)$ & - \\
\hline PT & $0,08208(2,8529)$ & $0,07752(2,78984)$ & $0,07395(2,583047)$ & $0,069518(2,51361)$ \\
\hline PDT & $0,04394(1,893)$ & $0,04085(1,85919)$ & $0,043916(1,8988)$ & $0,040902(1,866839)$ \\
\hline PFL & $0,00754(0,5351)$ & - & $0,009796(0,6907)$ & - \\
\hline PMDB & $0,0065(0,4640)$ & - & $0,003628(0,2590)$ & - \\
\hline PSDB & $0,0050(0,3411)$ & - & $0,004542(0,3104)$ & - \\
\hline Number Observations & 3427 & 3427 & 3427 & 3427 \\
\hline Adjusted R-squared & 0,926611 & 0,927036 & 0,926378 & 0,926785 \\
\hline Akaike info criterion & 0,335960 & 0,333679 & 0,339132 & 0,337113 \\
\hline Schwarz criterion & 0,377164 & 0,365926 & 0,380336 & 0,369360 \\
\hline Log likelihood: & $-552,6677$ & $-553,7597$ & $-558,1023$ & $-559,6431$ \\
\hline
\end{tabular}

Note: t-statistics are in brackets

${ }^{4}$ In the case of educational services, there is wide evidence that operating costs decrease with enrolment due to existence of high fixed costs. Consequently, larger schools tend to be more cost-efficient because the fixed costs are diluted among a higher number of students. This fact clearly discriminates against small municipalities since their schools have only a few students on average, and thus tend to present excessively high average costs. Were those cities larger, they would be able to enrol a greater number of students and reduce the cost per student without significant loss of educational quality. A similar explanation applies to other local public services. 
Notice that, contrary to the international evidence, in the Brazilian municipalities, the higher the proportion of people aged sixty or more, the lower the public expenditures. This is probably due to the fact that, in Brazil, older people are relatively well off when compared with the young and thus may afford to use private substitutes for local public goods. Remark that the fact that the old people are relatively well off in Brazil is endorsed by recent studies on poverty in Brazil (Neri (2000), Hoffman (2000)). On the other hand, the percentage of young people that is supposed to increase local expenditures was not significant.

Finally, regarding the impact of the mayor political party on the spending patterns, only the coefficients for the political parties PT and PDT were significant and positive at 5\% level, thus indicating that municipalities run by a mayor coming from these parties tend to spend more. This is consistent with the known characteristics of those political parties regarding the role of the government on local expenses.

\subsection{Quantile Regression Estimates}

To complement the econometric analysis carried out in the previous sub-section, we shall proceed to a more detailed investigation using quantile regression methods, as introduced by Koenker and Bassett (1978). Just as classical linear regression allows one to estimate models for conditional mean functions, quantile regression methods offer a mechanism for estimating models for the conditional median function, and also for other conditional quantile functions. The OLS estimate considers only the effect of one variable in the medium point of the conditional distribution of another dependent variable (expenditure, in this case). The use of the quantile regression method allows the analysis of the impact of explanatory variables on different points of the conditional distribution of the dependent variable. This allows us to investigate the impacts of the conditioning variables on local public expenses across different expenditures classes. Hence, one can examine the differences due to the structural heterogeneity of expenditures in various localities and the different effects of each variable depending on the expenditure class taken into consideration. The basic idea is to estimate the $\tau$-th quantile of efficiency conditional on the different explanatory variables, assuming that this quantile may be expressed as a linear predictor based on these variables ${ }^{5}$.

Consider $\left(y_{i}, x_{i}\right), i=1,2, \ldots, n$ a sample of a given population, in which $x_{i}$ is a vector of the $\mathrm{Kx} 1$ explanatory variables. The $\tau$-th quantile of $y$, the dependent variable, with $0<\tau<1$, is defined as: $\mathrm{Q}_{\mathrm{y}}(\tau)=\mathrm{F}^{-1}(\tau)=\inf \{\mathrm{y}: \mathrm{F}(\mathrm{y}) \geq \tau\}$, where $\mathrm{F}$ is the function of continuous distribution (nonconditioned) of $\mathrm{y}: \mathrm{F}(\mathrm{y})=\operatorname{Prob}(\mathrm{Y} \leq \mathrm{y})$. In the linear case, the dependent variable $y$ is an $x$ function on the form: $y_{i}=x_{i} \beta+\mu_{i}$, in which $\beta$ is the parameters vector and $\mu_{i}$ is the random errors vector. That configures the case of conditional quantiles of the distribution of $\mathrm{y}$, defined by the quantiles errors distribution: $\operatorname{Pr}\left(y_{i} \leq y / x_{i}\right)=F_{\mu \tau}\left(y-x_{i}^{\prime} \beta_{\tau} / x_{i}\right), i=1,2, \ldots, n$. The quantile function can be defined then, in the form: $Q_{\tau}\left(y_{i} / x_{i}\right)=x_{i}^{\prime} \beta_{\tau}+F_{\mu}{ }^{-1}(\tau)$. The $\beta_{\tau}$ estimated from the former quantile function, defined as an estimator of the quantile regression, is found as the solution of the following objective function:

\footnotetext{
${ }^{5}$ For further details on the method see Koenker \& Basset ( 1978, 1982), Buchinsky (1998), Koenker e Machado (1999) and Koenker \& Hallock, (2001).
} 


$$
\min 1 / \mathrm{n} \sum_{\substack{i: y_{i} \geq x \beta \\ \tau\left|y_{\mathrm{i}}-\mathrm{x}_{\mathrm{i}}^{\prime} \beta\right|}} \sum_{\substack{i: y_{i}<x \beta \\ i}}(1-\tau)\left|\mathrm{y}_{\mathrm{i}}-\mathrm{x}_{\mathrm{i}}^{\prime} \beta\right|=\min 1 / \beta \sum_{i=1}^{n} \rho_{\tau}\left(\mathrm{y}_{\mathrm{i}}-\mathrm{x}_{\mathrm{i}}^{\prime} \beta\right),
$$

in which $\rho$ (.) is the "check" function defined by: $\rho_{\tau}(\mathrm{z})=\{\tau \mathrm{z}$, se $\mathrm{z} \geq 0$; and $(\tau-1)$, se $\mathrm{z}<0\}$.

In this case, the minimization of absolute values to the conventional median function is observed, apart from the minimizing of squared residuals. The model specifies the conditional quantile function of the dependent variable $y$, given the explanatory variable matrix $X$ as: $Q_{y}(\tau \mid X)=$ $\mathrm{X} \beta(\tau), \tau=[0,1]$. The representation in form of the linear programming model makes the parameter estimating easier. The objective function, previously presented, is a weighted sum of absolute deviations, providing a robust localization measure, so that the estimated coefficient vector is not sensitive to extreme observations on the dependent variable. When the errors do not follow a regular distribution, the quantile regression estimators can be more efficient than the OLS estimators. Different solutions to distinct quantiles can be interpreted as differences on the dependent variable response to changes on the regressors in several points of the conditional distribution of the dependent variable.

The study of the asymptotic behavior of the quantile regression estimate, which allows inferring on the estimated coefficients, requires the following additional hypotheses: (Koenker \& Basset,1982): a) (density): the error distribution, $F_{\mu}$, has a continuous and strictly positive density, $\mathrm{f}_{\mu}$, to every $\mathrm{z}$, so that: $0<\mathrm{F}_{\mu}(\mathrm{z})<1$; b) (picture): the sequence $\left\{\mathrm{x}_{\mathrm{i}}\right\}$ satisfies $\mathrm{n}^{-1} \Sigma \mathrm{x}_{\mathrm{i}} \mathrm{x}_{\mathrm{i}}{ }^{\prime} \rightarrow$ $\mathrm{D}$, a defined positive matrix; and c) (scale): the sequence of scale functions takes the form $\sigma_{\mathrm{n}}(\mathrm{x})$ $=1+\mathrm{x} \gamma_{\mathrm{n}}$, in which $\gamma_{\mathrm{n}}=\gamma_{0} /(\mathrm{n})^{1 / 2}$, to some fixed $\gamma_{0} \in \mathbf{R}^{\mathrm{k}}$.

To i.i.d. errors there is: $(\mathrm{n})^{1 / 2}(\beta(\tau)-\beta(\tau)) \rightarrow \mathrm{N}\left(0, \Lambda_{\tau}\right)$, in which, $\Lambda_{\tau}=\left[\tau(1-\tau) / \mathrm{f}^{2}\left(\mathrm{~F}^{-1}(\tau)\right)\right] \mathrm{D}^{-1}$

Therefore, the asymptotic precision of the quantile regression estimate to i.i.d. errors depends basically on the quantity: $\mathrm{S}(\tau)=\left[\mathrm{f}\left(\mathrm{F}^{-1}(\tau)\right)\right]^{-1}$, usually called "sparsity" function (Tukey, 1975). To non-independent and identically distributed errors, the covariance matrix limit takes the form: $(\mathrm{n})^{1 / 2}(\beta(\tau)-\beta(\tau)) \rightarrow \mathrm{N}\left(0, \mathrm{H}_{\mathrm{n}}^{-1} \mathrm{~J}_{\mathrm{n}} \mathrm{H}_{\mathrm{n}}{ }^{-1}\right)$, in which $\mathrm{J}_{\mathrm{n}}(\tau)=\tau(1-\tau) \mathrm{n}^{-1} \Sigma \mathrm{x}_{\mathrm{i}} \mathrm{x}_{\mathrm{i}}{ }^{\prime}$; and $\mathrm{H}_{\mathrm{n}}(\tau)=\operatorname{lim~n}^{-1} \Sigma$ $\mathrm{x}_{\mathrm{i}} \mathrm{X}_{\mathrm{i}}{ }^{\prime} \mathrm{f}_{\mathrm{i}}\left(\xi_{\mathrm{i}}(\tau)\right)$ and in which $\mathrm{f}_{\mathrm{i}}\left(\xi_{\mathrm{i}}(\tau)\right)$ is the conditional density of the variable response yi estimated in $t$-th quintile. In the i.i.d. case, the $\mathrm{f}_{\mathrm{i}}\left(\xi_{\mathrm{i}}(\tau)\right)$ functions are identical and the "Huber Sandwich" equals the i.i.d. errors expression.

To make inference based on general hypotheses, we used the Wald's approach. As considered in Koenker \& Basset (1982), a general linear hypothesis can be adopted on the vector $\zeta=\left(\beta\left(\tau_{1}\right)^{\prime}, \ldots\right.$, $\left.\beta\left(\tau_{\mathrm{m}}\right)^{\prime}\right)$ ' from the form: $\mathrm{H}_{0}: \mathrm{H} \zeta=\mathrm{h}$.

The statistic test is: $T_{n}=(H \zeta-h)^{\prime}\left[H\left(\Omega \otimes\left(X^{\prime} X\right)^{-1}\right) H^{\prime}\right]^{-1}(H \zeta-h)$, which is asymptotically $\chi^{2}$ under $\mathrm{H}_{0}$. This formulation embraces a great variety of situations, of simple tests over a single coefficient to collective tests involving various coefficients and different quantiles. Therefore, it is possible, for instance, to test for the equality of the several slopes of coefficients among various quantiles.

We thus re-estimate the OLS models by using the techniques of quantile regression. In order to do that, we considered the following conditional quantiles: 0.10 (percentile 10\%), 0.25 (lower quartile), 0.50 (median), 0.75 (upper quartile) e 0.90 (percentile 90\%), that is $(\tau=0.10 ; 0.25$; 
$0.50 ; 0.75 ; 0.90)$. We used the estimation method "BR", proposed by Barrodale-Roberts), adequate for the case where the sample size has around 3500 observations and the only one that allows for the "rank test". The errors were considered not i.i.d, thus allowing for the presence of heteroskedasticity. Notice also that this method satisfy the criterion of "goodness-of-fit" (the "pseudo- $\mathrm{R}^{2}$ ) for model selection (see Koenker \& Machado, 1999). We kept the explanatory variables that proved to be statistically significant in the OLS model.

Results are shown in Table 3 and Table 4. Although confirming the ones found by using the OLS model, we obtain differentiated results according to the class of expenditure considered. The computed Wald statistics shows that the differences in the slopes are significant.

Table 3: Determinants of the Demand For Local Public Goods in Brazilian Municipalities - 2000 - Quantile Regression Results - Model 2

\begin{tabular}{|c|c|c|c|c|c|}
\hline \multicolumn{6}{|c|}{ Dependent Variables: Aggregate Municipalities' Expenditures by Quintiles } \\
\hline Variables & 0,10 & 0,25 & 0,50 & 0,75 & 0,90 \\
\hline Intercept & $\begin{array}{l}6,12289 \text { *** } \\
(0,19232)\end{array}$ & $\begin{array}{l}5,74331 * * * \\
(0,19055)\end{array}$ & \begin{tabular}{|l}
$5,73803 * * *$ \\
$(0,19001)$
\end{tabular} & $\begin{array}{l}, 93698 * * * \\
(0,24631)\end{array}$ & \begin{tabular}{|l}
$5,73624 * * * *$ \\
$(0,38134)$
\end{tabular} \\
\hline Distance & $\begin{array}{l}0,03343 \text { *** } \\
(0,00557)\end{array}$ & $\begin{array}{l}0,03481 * * * \\
(0,00592)\end{array}$ & $\begin{array}{l}0,04147 * * * \\
(0,00594)\end{array}$ & $\begin{array}{l}0,04394 * * * \\
(0,00761)\end{array}$ & $\begin{array}{l}0,05021 \text { *** } \\
(0,01177)\end{array}$ \\
\hline Tax share & $\begin{array}{l}-0,0218 * * * \\
(0,00457)\end{array}$ & $\begin{array}{l}-0,0188 * * * \\
(0,00454)\end{array}$ & \begin{tabular}{|l|}
$-0,0266 * * *$ \\
$(0,00446)$
\end{tabular} & $\begin{array}{l}-0,0356 * * * \\
(0,00567)\end{array}$ & $\begin{array}{l}-0,0466 * * * \\
(0,00871)\end{array}$ \\
\hline Median Income & $\begin{array}{l}0,30369 \text { **** } \\
(0,02166)\end{array}$ & $\begin{array}{l}0,39370 * * * \\
(0,02169)\end{array}$ & \begin{tabular}{|l|}
$0,42744 * * *$ \\
$(0,02224)$
\end{tabular} & $\begin{array}{l}0,46384 * * * \\
(0,02906)\end{array}$ & $\begin{array}{l}0,55115 \text { **** } \\
(0,04284)\end{array}$ \\
\hline Capital & $\begin{array}{l}0,64900 * * \\
(0,32726)\end{array}$ & $\begin{array}{l}0,75830 * * * \\
(0,17014)\end{array}$ & $\begin{array}{l}0,80387 * * * \\
(0,10875)\end{array}$ & $\begin{array}{l}0,85447 \text { *** } \\
(0,11990)\end{array}$ & \begin{tabular}{|l}
0,63370 **** \\
$(0,21974)$ \\
\end{tabular} \\
\hline Demographic Density & $\begin{array}{l}-0,0628 * * * \\
(0,00527)\end{array}$ & $\begin{array}{l}-0,0639 * * * \\
(0,00662)\end{array}$ & \begin{tabular}{|l|}
$-0,0723 * * *$ \\
$(0,00681)$
\end{tabular} & $\begin{array}{l}-0,0632 * * * \\
(0,00813)\end{array}$ & $\begin{array}{l}-0,0541 * * * \\
(0,01296)\end{array}$ \\
\hline Hospital & $\begin{array}{l}0,04990 \text { **** } \\
(0,01016)\end{array}$ & $\begin{array}{l}0,04554 * * * \\
(0,00925)\end{array}$ & $\begin{array}{l}0,04630 * * * \\
(0,00859)\end{array}$ & $\begin{array}{l}0,05613 \text { *** } \\
(0,01057)\end{array}$ & \begin{tabular}{|l}
0,05293 **** \\
$(0,01737)$
\end{tabular} \\
\hline Enrollment & $\begin{array}{l}0,08720 * * * \\
(0,00689)\end{array}$ & $\begin{array}{l}0,08052 * * * \\
(0,00704)\end{array}$ & \begin{tabular}{|l|}
$0,08955^{* * *} *$ \\
$(0,00709)$
\end{tabular} & $\begin{array}{l}0,08513 * * * \\
(0,00882)\end{array}$ & \begin{tabular}{|l}
0,07687 **** \\
$(0,01338)$ \\
\end{tabular} \\
\hline Participation in Inter- Municipal Consortia & $\begin{array}{l}-0,0250^{*} \\
(0,01338)\end{array}$ & $\begin{array}{l}-0,0333 * * * \\
(0,01199) \\
\end{array}$ & $\begin{array}{l}-0,0193 \\
(0,01202) \\
\end{array}$ & $\begin{array}{l}-0,0342 * * \\
(0,01493)\end{array}$ & \begin{tabular}{|l|}
$-0,0728 * * *$ \\
$(0,02233)$ \\
\end{tabular} \\
\hline Total Population & $\begin{array}{l}0,70626 \text { *** } \\
(0,01221)\end{array}$ & $\begin{array}{l}0,70509 * * * \\
(0,01111)\end{array}$ & $\begin{array}{l}0,69115 * * * \\
(0,01097)\end{array}$ & $\begin{array}{l}0,66388 * * * \\
(0,01337)\end{array}$ & \begin{tabular}{|l}
0,65235 **** \\
$(0,02131)$
\end{tabular} \\
\hline$\%$ Population $>60$ years old & $\begin{array}{l}-0,0223 * * * \\
(0,0075)\end{array}$ & $\begin{array}{l}-0,0235 * * * \\
(0,0084)\end{array}$ & \begin{tabular}{|l|}
$-0,0362 * * *$ \\
$(0,00887)$
\end{tabular} & $\begin{array}{l}-0,0582 * * * \\
(0,01049)\end{array}$ & $\begin{array}{l}-0,0708 * * * \\
(0,01641)\end{array}$ \\
\hline Polígono da Seca & $\begin{array}{l}-0,02824 \\
(0,02454) \\
\end{array}$ & $\begin{array}{l}-0,02983^{*} \\
(0,01610)\end{array}$ & \begin{tabular}{|l|}
$-0,03230 * *$ \\
$(0,01628)$ \\
\end{tabular} & $\begin{array}{l}-0,0624 * * * \\
(0,01992)\end{array}$ & $\begin{array}{l}-0,05102^{*} \\
(0,02806)\end{array}$ \\
\hline Northeast Region & $\begin{array}{l}-0,01893 \\
(0,02543)\end{array}$ & \begin{tabular}{|l|l}
0,03533 \\
$(0,02204)$ \\
\end{tabular} & $\begin{array}{l}0,05153 * * \\
(0,02268) \\
\end{array}$ & $\begin{array}{l}0,06406^{* *} \\
(0,028113)\end{array}$ & \begin{tabular}{|l|}
$0,09744 * *$ \\
$(0,03860)$
\end{tabular} \\
\hline Northern Region & $\begin{array}{l}-0,1879 * * * \\
(0,01556)\end{array}$ & $\begin{array}{l}-0,1811 * * * \\
(0,02410)\end{array}$ & \begin{tabular}{|l|}
$-0,1252 * * *$ \\
$(0,03745)$
\end{tabular} & $\begin{array}{l}-0,1270 * * * \\
(0,04278)\end{array}$ & $\begin{array}{l}-0,11320 \\
(0,07018)\end{array}$ \\
\hline Southeast Region & $\begin{array}{l}0,04711 \text { *** } \\
(0,01460)\end{array}$ & $\begin{array}{l}0,07340 * * * \\
(0,01370)\end{array}$ & \begin{tabular}{|l}
$0,08301 * * *$ \\
$(0,01353)$
\end{tabular} & $\begin{array}{l}0,13276 \text { *** } \\
(0,01863)\end{array}$ & \begin{tabular}{|l}
0,20816 **** \\
$(0,02806)$
\end{tabular} \\
\hline PT & $\begin{array}{l}0,05687 \text { *** } \\
(0,01249)\end{array}$ & $\begin{array}{l}0,05475^{*} \\
(0,03301)\end{array}$ & \begin{tabular}{|l|}
0,04329 \\
$(0,04708)$
\end{tabular} & $\begin{array}{l}0,16615 * * * \\
(0,02356)\end{array}$ & \begin{tabular}{|l|}
0,12044 \\
$(0,07820)$
\end{tabular} \\
\hline PDT & $\begin{array}{l}0,02263 \\
(0,04219)\end{array}$ & $\begin{array}{l}0,02639 \\
(0,01964)\end{array}$ & $\begin{array}{l}0,04035^{*} \\
(0,02259)\end{array}$ & $\begin{array}{l}0,02779 \\
(0,03478)\end{array}$ & $\begin{array}{l}0,05919 \\
(0,06818)\end{array}$ \\
\hline
\end{tabular}

Notes: a) the results in brackets stand for the estimated parameters standard errors; b) * significant parameter in $1 \%$; ** significant parameter in 5\%; *** significant parameter in $10 \%$, 
Table 4: Determinants of the Demand For Local Public Goods in Brazilian Municipalities - 2000 - Quantile Regression Results - Model 4

\begin{tabular}{|c|c|c|c|c|c|}
\hline \multicolumn{6}{|c|}{ Dependent Variables: Aggregate Municipalities' Expenditures by Quintiles } \\
\hline Variables & 0,10 & 0,25 & 0,50 & 0,75 & 0,90 \\
\hline Intercept & $\begin{array}{l}5,42094 * * * \\
(0,16267)\end{array}$ & $\begin{array}{l}4,85312 * * * \\
(0,13593)\end{array}$ & $\begin{array}{l}4,81122 \text { *** } \\
(0,14750)\end{array}$ & $\begin{array}{l}4,68053^{* * *} \\
(0,17105)\end{array}$ & $\begin{array}{l}4,18793 * * * \\
(0,28575)\end{array}$ \\
\hline Distance & $\begin{array}{l}0,03422^{* * *} \\
(0,00644)\end{array}$ & $\begin{array}{l}0,04040 * * * \\
(0,00550)\end{array}$ & $\begin{array}{l}0,04059 \text { **** } \\
(0,00583)\end{array}$ & $\begin{array}{l}0,04665 * * * \\
(0,00657)\end{array}$ & $\begin{array}{l}0,05694 * * * \\
(0,01147)\end{array}$ \\
\hline Tax share & $\begin{array}{l}-0,1316^{* * * *} \\
(0,03193)\end{array}$ & $\begin{array}{l}-0,1423 * * * \\
(0,02442)\end{array}$ & $\begin{array}{l}-0,1450 * * * \\
(0,02631)\end{array}$ & $\begin{array}{l}-0,1534 * * * \\
(0,03161)\end{array}$ & $\begin{array}{l}-0,19835^{* * *} \\
(0,04951)\end{array}$ \\
\hline Median Income & $\begin{array}{l}0,33574 * * * \\
(0,02303)\end{array}$ & $\begin{array}{l}0,44749 * * * \\
(0,01930)\end{array}$ & \begin{tabular}{|l}
$0,49596 * * * *$ \\
$(0,02216)$
\end{tabular} & \begin{tabular}{|l|}
$0,54862 * * *$ \\
$(0,02643)$
\end{tabular} & $\begin{array}{l}0,64299 * * * \\
(0,04223)\end{array}$ \\
\hline Capital & $\begin{array}{l}0,64881 * * \\
(0,27121)\end{array}$ & $\begin{array}{l}0,69866^{* * *} \\
(0,12592)\end{array}$ & $\begin{array}{l}0,79575 \text { **** } \\
(0,09734)\end{array}$ & $\begin{array}{l}0,78972 * * * \\
(0,09735)\end{array}$ & $\begin{array}{l}0,69460 * * \\
(0,34679)\end{array}$ \\
\hline Demographic Density & $\begin{array}{l}-0,0608 * * * \\
(0,00725)\end{array}$ & $\begin{array}{l}-0,06804 * * * * \\
(0,00605)\end{array}$ & $\begin{array}{l}-0,0680 * * * \\
(0,00660)\end{array}$ & $\begin{array}{l}-0,0656 * * * \\
(0,00749)\end{array}$ & $\begin{array}{l}-0,06293 \text { **** } \\
(0,01259)\end{array}$ \\
\hline Hospital and Health Services & $\begin{array}{l}0,04842^{* * * *} \\
(0,01080)\end{array}$ & $\begin{array}{l}0,03522 * * * \\
(0,00840)\end{array}$ & $\begin{array}{l}0,03848^{* * * *} \\
(0,00842)\end{array}$ & $\begin{array}{l}0,05462 * * * \\
(0,01067)\end{array}$ & $\begin{array}{l}0,05465 * * * \\
(0,01702)\end{array}$ \\
\hline Enrollment & $\begin{array}{l}0,09675^{* * *} \\
(0,00711)\end{array}$ & $\begin{array}{l}0,08722 * * * \\
(0,00610)\end{array}$ & \begin{tabular}{|l}
0,08975 **** \\
$(0,00694)$
\end{tabular} & $\begin{array}{l}0,09226 * * * \\
(0,00781)\end{array}$ & \begin{tabular}{|l|}
$0,08579 * * *$ \\
$(0,01294)$
\end{tabular} \\
\hline Participation in Inter- Municipal Consortia & $\begin{array}{l}-0,02723 * * \\
(0,01074)\end{array}$ & $\begin{array}{l}-0,02042 * * \\
(0,01049)\end{array}$ & $\begin{array}{l}-0,02082 * * \\
(0,01159)\end{array}$ & $\begin{array}{l}-0,0454 * * * \\
(0,01221) \\
\end{array}$ & $\begin{array}{l}-0,08352 * * * \\
(0,02249)\end{array}$ \\
\hline Total Population & $\begin{array}{l}0,73001 * * * \\
(0,01074)\end{array}$ & $\begin{array}{l}0,73021 * * * \\
(0,00862)\end{array}$ & $\begin{array}{l}0,71832 \text { **** } \\
(0,00920)\end{array}$ & $\begin{array}{l}0,70049 \text { *** } \\
(0,0107)\end{array}$ & $\begin{array}{l}0,6957 * * * \\
(0,01830)\end{array}$ \\
\hline$\%$ Population $>60$ years old & $\begin{array}{l}0,01081^{*} \\
(0,00652)\end{array}$ & $\begin{array}{l}-0,00223 \\
(0,00543)\end{array}$ & $\begin{array}{l}-0,00276 \\
(0,00622)\end{array}$ & \begin{tabular}{|l|}
$-0,0082$ \\
$(0,00726)$
\end{tabular} & \begin{tabular}{|l|}
$-0,00784$ \\
$(0,01200)$
\end{tabular} \\
\hline Draught Area (Polígono da Seca ) & $\begin{array}{l}-0,01348 \\
(0,02482)\end{array}$ & $\begin{array}{l}-0,01902 \\
(0,01605)\end{array}$ & $\begin{array}{l}-0,02094 \\
(0,01452)\end{array}$ & $\begin{array}{l}-0,0492 * * * \\
(0,01713)\end{array}$ & $\begin{array}{l}-0,04105 \\
(0,03105)\end{array}$ \\
\hline Northeast Region & $\begin{array}{l}-0,02069 \\
(0,02812)\end{array}$ & $\begin{array}{l}0,06589 * * * \\
(0,02127)\end{array}$ & $\begin{array}{l}0,06809 \text { **** } \\
(0,0222)\end{array}$ & $\begin{array}{l}0,08272 * * * \\
(0,02413)\end{array}$ & $\begin{array}{l}0,12115 * * * \\
(0,04215)\end{array}$ \\
\hline Northern Region & $\begin{array}{l}-0,1938 * * * \\
(0,01594)\end{array}$ & $\begin{array}{l}-0,1631 * * * \\
(0,03496)\end{array}$ & $\begin{array}{l}-0,1485 * * * \\
(0,04170)\end{array}$ & \begin{tabular}{|l|}
$-0,1392 * * *$ \\
$(0,03486)$
\end{tabular} & \begin{tabular}{|l}
$-0,10870 * * *$ \\
$(0,04491)$
\end{tabular} \\
\hline Southeast Region & $\begin{array}{l}0,03902 * * * \\
(0,01455)\end{array}$ & $\begin{array}{l}0,0676 \text { *** } \\
(0,01207) \\
\end{array}$ & \begin{tabular}{|l}
0,08515 *** \\
$(0,01364)$ \\
\end{tabular} & $\begin{array}{l}0,13440 * * * \\
(0,01693) \\
\end{array}$ & \begin{tabular}{|l|}
$0,20453 * * *$ \\
$(0,02722)$ \\
\end{tabular} \\
\hline PT & $\begin{array}{l}0,05381 * * * \\
(0,02061)\end{array}$ & $\begin{array}{l}0,06075^{*} \\
(0,03682)\end{array}$ & $\begin{array}{l}0,06224 \\
(0,03938)\end{array}$ & $\begin{array}{l}0,15238^{* * *} \\
(0,01314)\end{array}$ & $\begin{array}{l}0,06552 \\
(0,06304)\end{array}$ \\
\hline PDT & $\begin{array}{l}0,01049 \\
(0,04528)\end{array}$ & $\begin{array}{l}0,03688^{*} \\
(0,02509)\end{array}$ & $\begin{array}{l}0,03850 * \\
(0,02063)\end{array}$ & \begin{tabular}{|l|}
0,02303 \\
$(0,03485)$
\end{tabular} & $\begin{array}{l}0,06633 \\
(0,06698)\end{array}$ \\
\hline
\end{tabular}

Notes: a) the results in brackets stand for the estimated parameters standard errors; b) * significant parameter in $1 \%$; ** significant parameter in $5 \%$; *** significant parameter in $10 \%$,

Firstly, as expected, the relevance of neighborhood effect increases along the expenditure classes suggesting that the spillover effect tends to be higher on larger cities. The metropolitan region is a well-known example of this impact. Notice also the impact of the tax price increases along the expenditure classes. This is probably due to the fact that municipalities presenting higher expenses tend to have a more diversified tax base; their higher tax price elasticities reflect this larger diversification as well as the fact that they are more integrated into the market economy. Confirming the OLS results, we find that income and population are strong determinants of the demand for local public services. As expected, for income, the impact increases with the expenditure class thus showing that higher levels of development bring about increased pressures for those services. As for the population, the decreasing effect across expenditures classes 
suggests the existence of economies of agglomeration. Consistent with this result, the impact of the demographic density variable firstly increases and after median expenditure classes diminishes across the higher expenditure classes. This is not surprisingly as the economies of scale in Brazil affect mostly the small cities, unable to wipe off the high fixed costs that characterizes the production patterns of local public services. Once cities reach a certain level of size, the agglomeration benefits begin to peter out, while diseconomies rise rapidly. By the same token, the participation in inter-municipal consortia contributes to reduce public expenditures. The inverse relationship between expenditure and participation in inter-municipal consortia was caused by economies of scale prevalent among small municipalities. Yet, here, the results show that this effect is quite widespread, thus suggesting that even medium sized and relatively big cities cannot reach the optimum size for hospitals, for instance, and thus seek to join consortia in an attempt to reduce costs. From the efficiency aspect, this is a quite important result as it builds up a much-required coordination among municipal administrations.

Results for the congestion effects, for the various percentiles are shown in Table 5. They suggest that the crowding parameters are, as in the aggregated case, below the unity. The impact of the city size on the quality of club goods shows crowding effects as $\gamma$ is between zero and one. However, in both models, marginal congestion slightly decreases with expenditure. This is a rather surprising result as one is tempted to conclude that the congestion effect should be higher on big cities. Yet, a more careful look shows the drawbacks of such interpretation. The indivisibilities that preclude the provision of certain services in small towns, concentrate their provision on larger cities. Hence, the higher expenditures of those big cities reflect not only a crowding cost but also the fact that these towns offer a wide range of services when compared to the small ones. Confirming these results, the health indicator shows a higher coefficient for the last quintile as only those big cities have big hospitals and health centers that perform complex and expensive medical procedures. So, in Brazil, contrary to the traditional results, the reduced congestion effect along the spending classes reflect the predominance of the scale elements measured by the population elasticities over the price effects.

Table 5: Congestion Parameter Along Expenditures Classes

\begin{tabular}{c|c|c|c|c|c}
\hline \multirow{2}{*}{ Congestion Parameter } & \multicolumn{5}{|c}{ Classes of Expenditure } \\
\cline { 2 - 6 } & 0,10 & 0,25 & 0,50 & 0,75 & 0,90 \\
\hline \multirow{2}{*}{ Model 2 } & 0,69971 & 0,69944 & 0,68271 & 0,65147 & 0,63536 \\
\hline \multirow{2}{*}{ Model 4 } & 0,68909 & 0,68545 & 0,67055 & 0,64622 & 0,62041 \\
\hline
\end{tabular}

Source: our calculations

As for the population and enrollment variables, the corresponding elasticities are smaller the higher the expenditure class, a clear sign that are grounds to exploit the scale economies in the Brazilian communes. The impact of the structure of the population on expenditures is strongly 
affected by the tax price calculation. When the tax share is based on the municipal share of total revenues the results confirm those obtained on the aggregate analysis. Yet, as we define the tax price as the ratio between the median and average income, the results change; except for the first quintile, the coefficients have the expected sign but are not significant.

Concerning the localization effects, the fact of being a capital has a significant impact on the dependent variable, particularly, for those, which are in the middle range of expenditure. This is probably due to the fact that medium sized capital cities have not yet reach the point where the economies of agglomeration are exhausted. Notice also that municipalities located in the Northeast and Southeast regions tend to have higher demand for local public goods. The only exceptions are the northeast cities located in the lower quintile; being one of those towns has a negative but non-significant impact on spending. This is probably due to the fact most of those cities are situated in the draught area. As for the North region, the negative impact found on the aggregate levels decreased with the expenditure classes showing that the factor behind those results are less prevalent among larger cities.

Finally, the political variables - the mayor belonging to the PT or PDT parties - showed positive effects on the expenditure. This is a reasonable result considering these are parties that strongly defend governmental participation in the country's economy, The results, however, are not significant to the extremities of the expenditure classes.

\section{CONCLUDING REMARKS}

In this paper we estimated the demand for local public spending for the Brazilian municipalities within a median voter's framework. Results obtained are consistent with the theoretical background thus suggesting that this hypothesis might be useful to describe the demand for local public goods in Brazil. In particular, the use of quantile regression permitted to investigate the impacts of the conditioning variables on local public expenses across different expenditures classes thus allowing for heterogeneity across municipalities.

Confirming previous results we found out that the main variables in this model - price, income and population - were significantly and had the expected sign. Specifically, we found that the income elasticities indicates that municipal public spending in Brazil is not a luxury although our estimates are clearly above the international average, according to which those goods conform more to the pattern of "basic" needs. Finally, as expected, a higher population increases the demand for public goods.

Our results also suggest that the impact of the city size on the quality of club goods shows crowding effects as $\gamma$ is between zero and one. However, in the estimated models, marginal congestion slightly decreases with expenditure. This is a rather surprising result as one is tempted to conclude that the congestion effect should be higher on big cities. Yet, a more careful look shows the drawbacks of such interpretation. The indivisibilities that preclude the provision of certain services in small towns, concentrate their provision on larger cities. Hence, the higher expenditures of those big cities reflect not only a crowding cost but also the fact that these towns offer a wide range of services when compared to the small ones. So, in Brazil, contrary to the traditional results, the reduced congestion effect along the spending classes reflect the predominance of the scale elements measured by the population elasticities over the price effects. 
The natural extension of our current investigation would be to include a more detailed description of the spillover effects that characterizes the demand for public goods, particularly on the metropolitan areas. This will give a more complete perception of demand for local public services in the Brazilian municipalities.

\section{REFERENCES}

ARONSSON, T., LUNDBERG, J., AND WIKSTROM (2000) "The Impact of Regional Public Expenditure on the Local Decision to Spend." Regional Science and Urban Economics 30: 185-202.

BAUDRY, M., M. LEPRINCE AND C. MOREAU (2002) "Préférences Révélées, Bien Public Local et Electeur Médian: Tests sur Données Françaises." Économie et Prévision 156: 125145.

BERGSTROM, T. C. GOODMAN, R. P. (1973) "Private Demands for Public Goods." The American Economic Review 63: 280-296.

BERGSTROM, T. C. RUBINFELD, D. L. SHAPIRO, P. (1982) "Micro-Based Estimates of Demand Functions for Local School Expenditures." Econometrica, 50: 1183-1205.

BLACK, D. (1969) "On the Rationale of Group Decision Making." In Readings in Welfare Economics, The American Economic Association, published by Richard D, Irwin, Inc, Homewood, Illinois.

BLECHA, B. (1987) “The Crowding Parameter and Samuelsonian Publicness." Journal of Political Economy 95: 622-631.

BORCHERDING., T., AND R.T. DEACON (1972) "The Demand for the Services of NonFederal Governments." American Economic Review 62: 891-901,

BUCHINSKY, M. (1998) "Recent Advances in Quantile Regression Models: A Practical Guideline for Empirical Research." JHR 33: 88-126.

CONGLETON, R. D. (2001) "Rational Ignorance, Rational voter Expectations and Public Policy: A Discrete Informational Foundation Problem.” Public Choice 107: 35-64.

CONGLETON R. D. and BENNET, R. W. (1995) "On the Political Economy of state Highway Expenditures: Some Evidence of the Relative Performance of Alternative Public Choice Models. " Public Choice 84: 1-24.

CONGLETON R. D. and W.F. SHUGHART (1990) "The Growth of Social Security: Electoral Push or Political Pull?" Economic Inquiry 28: 109-132.

DAHLBERG, M. and E. JOHANSSON (1998) "The Revenues Expenditures Nexus: Panel Data Evidence from Swedish Municipalities.” Applied Economics 30: 1379-1386.

DAHLBERG, M. and E. JOHANSSON (2000) "An Examination of the Dynamic Behavior of Local Governments using GMN Bootstrapping Methods." Journal of Applied Econometrics 15: 401-416.

DEACON, R. T. (1978) “A Demand Model for the Local Public Sector.” Review of Economics and Statistics 60: 184-192.

DOI, T. (1998) "New Evidence on the Median Voter Hypothesis in Japan." Institute of Social Science, University of Tokyo, Japan, www.iss.u-tokyo.ac.jp/Paper/pdffile/f-72.pd.

GUENGANT, A., J.M. JOSSELIN AND Y. ROCABOY (2002) "Effects of Club Size in the Provision of Public Goods: Network and Congestion Effects in the Case of the French Municipalities." Papers in Regional Science 81: 443-460.

GROSS, J. (1995) "Heterogeneity of Preferences for Local Public Goods: The case of private Expenditures on Public Education.” Journal of Public Economics 57: 103-127.

HOFFMANN, R. (2000) "Mensuração da Desigualdade e da Pobreza no Brasil." Em Henriques, R., ed., Desigualdades e Pobreza no Brasil.IPEA, Rio de Janeiro, RJ. 
KOENKER, R. and BASSETT, G. (1978), "Regression Quantiles.” Econometrica 46: 33-50.

(1982) "Robust Tests for Heteroskedasticity based on Regression Quantiles.” Econometrica 50: 43-61.

KOENKER, R., HALLOCK, K. (2001) “Quantile Regression.” JEP, 15: 143-156.

KOENKER, R. AND MACHADO, J. (1999) "Goodness of Fit and Related Inference Processes for Quantile Regression.” JASA, 84: 1296-1310.

NERI, M. (2000) "Políticas Estruturais de Combate à Pobreza no Brasil." Em Henriques, R., ed., Desigualdades e Pobreza no Brasil. IPEA, Rio de Janeiro, RJ.

REITER, M., AND A. WEICHENRIEDER (1997) "Are Public Goods Public? A Critical Survey of the Demand Estimates for Local Public Services.” Finanzarchiv 54: 374-408.

REITER, M., AND A. WEICHENRIEDER (1999) "Public Goods, Club Goods and the Measurement of Crowding." Journal of Urban Economics 46: 69-79.

RUBINFELD, D. L. (1983) “The Economics of the Local Public Sector.” In Handbook of Public Economics, Vol II, Cap, 11, 571-645.

SAMUELSON, P. (1954) "The Pure Theory of Public Expenditure." Review of Economics and Statistics 36: 387-389.

SAMPAIO DE SOUSA, M. C. AND STOSIC, B. D. (2003) "Technical Efficiency of the Brazilian Municipalities: Correcting Non-Parametric Frontier Measurements for Outliers." Departamento de Economia, Working Paper 294, University of Brasilia, Brazil, June.

SAMPAIO DE SOUSA, M.C. CRIBARI NETO, F., AND STOSIC, B. D. (2003) "Explaining DEA Technical Efficiency Scores in an Outlier Corrected Environment: The Case of Public Services in the Brazilian Municipalities." Mimeo.

TIEBOUT, C. M. (1956) "A Pure Theory of Local Expenditures." The Journal of Political Economy 64: 416-424.

TUKEY, J, W, (1975), "Instead of Gauss-Markov Least Squares, What?" Applied Statistics, Amsterdam: North-Holland,

TURNBULL, G.K. AND S.S. DJOUNDOURIAN (1994) "The Median Voter Hypothesis: Evidence from General Purpose Local Governments." Public Choice 81: 223-240.

TURNBULL, G.K, AND CHANG (1998) "The Median Voter According to GARP." Southern Economic Journal 64: 1001-1010.

VARIAN, H. (1982) "The Nonparametric Approach to Demand analysis." Econometrica 50: 945-973.

VARIAN, H. (1990) "Goodness of Fit in Optimizing Models." Journal of Econometrics 50: 125140. 